\title{
Pemetaan dan Analisis Faktor yang Memengaruhi Persentase Usaha E-Commerce di Indonesia
}

\author{
Wahyuni Windasari *, dan Tuti Zakiyah * \\ * Universitas Putra Bangsa \\ Fakultas Ekonomi dan Bisnis \\ Jl. Ronggowarsito No. 18, Kebumen 54361, Indonesia \\ E-mail: wahyuwindasari@gmail.com
}

\begin{abstract}
Abstrak
Perkembangan informasi dan teknologi membawa dampak pada pertumbuhan E-Commerce di Indonesia. Sebagai pasar E-Commerce besar di ASEAN, persebaran E-Commerce di Indonesia masih terkonsentrasi di Pulau Sumatera dan Jawa. Kondisi ini mengindikasikan masih belum meratanya usaha E-Commerce di Indonesia. Pada penelitian ini dibahas terkait ada tidaknya pengaruh faktor spasial atau kewilayahan pada persentase usaha E-Commerce di Indonesia. Metode yang digunakan adalah Geographical Weighted Regression (GWR). Hasil analisis mengklasifikasikan 34 provinsi di Indonesia menjadi lima kelompok berdasarkan model signifikan yaitu (1) Enam provinsi di Indonesia signifikan terhadap pertumbuhan ekonomi, (2) Sembilan provinsi signifikan terhadap keahlian di bidang TIK, (3) Dua provinsi signifikan terhadap keahlian di bidang TIK dan ketersediaan BTS, (4) Tiga provinsi signifikan terhadap keahlian di bidang TIK dan pertumbuhan ekonomi, (5) Empat belas provinsi di Indonesia tidak signifikan terhadap variabel prediktor yang digunakan pada penelitian ini.
\end{abstract}

Kata kunci: E-Commerce, Spasial, GWR

\begin{abstract}
The development of information and technology has an impact on the growth of E-Commerce in Indonesia. As a large E-Commerce market in ASEAN, E-Commerce business in Indonesia is still centered in Java and Sumatra. This shows that the development of E-Commerce is still not equal. This research discusses whether there is an influence of spatial or territorial factors on the percentage of E-Commerce businesses in Indonesia. The method used is Geographical Weighted Regression (GWR). The results of the analysis classify 34 provinces in Indonesia into five groups based on a significant model, namely (1) Six provinces in Indonesia are significant for economic growth, (2) Nine provinces are significant for expertise in the ICT sector, (3) Two provinces are significant for expertise in the ICT sector and availability of BTS, (4) Three provinces are significant for expertise in ICT and economic growth, (5) Fourteen provinces in Indonesia are not significant for the predictor variables used in this study.
\end{abstract}

Keywords: E-Commerce, Spatial, GWR

\section{Pendahuluan}

Kemajuan komunikasi dan teknologi informasi membawa dampak pada berbagai aktivitas manusia, termasuk di dalamnya gaya hidup dan pola konsumsi masyarakat. Penerapan gaya hidup less cash society, membuat sebagian besar masyarakat Indonesia menggunakan kemajuan komunikasi dan teknologi informasi untuk melakukan transaksi jual dan atau beli barang maupun jasa secara online atau yang sering disebut dengan perdagangan elektronik (E-Commerce).

Berdasarkan data dari Merchant Machine (2019), Indonesia menduduki peringkat pertama negara dengan pertumbuhan E-Commerce tercepat di dunia pada tahun 2018 dengan angka pertumbuhan sebesar 78\%. Angka pertumbuhan E-Commerce ini bahkan melebihi angka pertumbuhan ekonomi di Indonesia pada tahun yang sama yaitu sebesar $5.17 \%$ (BPS, 2019). Hal ini menandakan, E-Commerce dapat menjadi pendorong dan wajah baru perekonomian di Indonesia. Menurut Lastri dan Anis (2020), E-Commerce berpengaruh signifikan dan positif terhadap pertumbuhan ekonomi baik jangka panjang maupun jangka pendek.

Di sisi lain, pelaku usaha di Indonesia yang memanfaatkan E-Commerce masih terbilang rendah. Pelaku bisnis online baru sejumlah $15 \%$ dari total 
pelaku usaha di Indonesia dengan persentase usaha E-Commerce tertinggi berada di pulau Jawa (Badan Pusat Statistik, 2019).

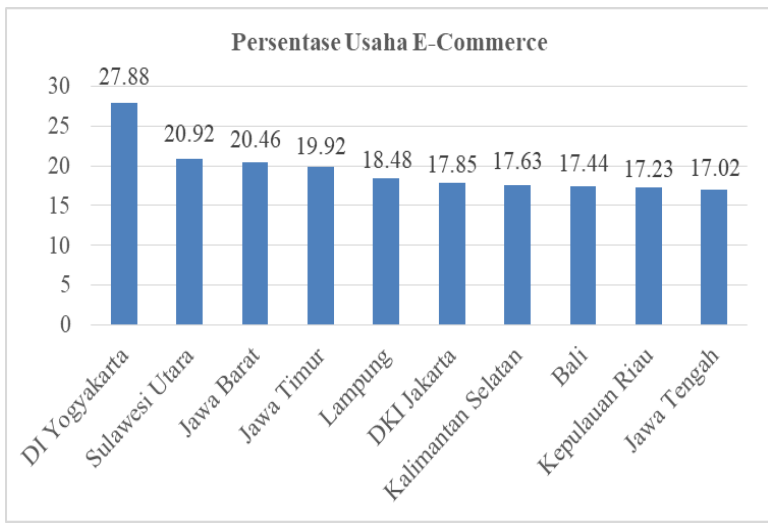

Gambar 1: Sepuluh Besar Provinsi dengan Persentase Usaha E-Commerce Tahun 2019 (BPS, 2019)

Dari Gambar 1 terlihat bahwa sekitar $50 \%$ provinsi yang menduduki sepuluh besar persentase usaha E-Commerce berada di Pulau Jawa. Banyaknya pelaku usaha konvensional dibandingkan pelaku usaha online serta masih terpusatnya usaha E-Commerce di pulau besar di Indonesia menjadi suatu alasan yang menarik untuk diteliti lebih lanjut perihal faktor yang mempengaruhi perkembangan E-Commerce di Indonesia. Ramadhan (2019) meneliti tentang pengaruh pengguna E-Commerce, pengguna internet, dan PDB Per kapita terhadap perkembangan E-Commerce dengan menggunakan analisis panel simultan EC2SLS. Hasil penelitian menunjukkan bahwa PDB per kapita merupakan faktor yang memiliki pengaruh paling besar terhadap perkembangan E-Commerce.

Selanjutnya, penelitian Muslim (2020) menjelaskan bahwa Indeks Pembangunan Manusia, persentase desa dengan jaringan internet $4 \mathrm{G}$, persentase desa dengan ketersediaan stasiun pemancar serta pertumbuhan ekonomi merupakan faktor yang memberikan kontribusi pada persentase usaha E-Commerce. Selain itu, dalam penelitiannya menunjukkan juga bahwa usaha E-Commerce dan pertumbuhan ekonomi memengaruhi satu dengan lainnya secara simultan spasial.

Berdasarkan latar belakang dan penelitian sebelumnya, analisis faktor yang mempengaruhi perkembangan E-Commerce dilakukan secara global maka pada pengkajian ini akan dianalisis faktor-faktor yang memengaruhi usaha E-Commerce di Indonesia secara lokal dengan memperhatikan unsur region sebagai efek spasial.

\section{Landasan Teori}

\section{Persentase Usaha E-Commerce}

Perbandingan jumlah pelaku usaha yang memanfaatkan internet guna menerima pesanan atau melakukan penjualan baik barang maupun jasa dengan total pelaku usaha secara keseluruhan (BPS, 2019). Provinsi dengan nilai persentase usaha E-Commerce yang tinggi menandakan jumlah usaha E-Commecer lebih banyak dibandingkan dengan jumlah usaha konvensional.

\section{Pertumbuhan Ekonomi}

Menurut Sadono (2000) terdapat beberapa alat ukur untuk pertumbuhan ekonomi. Salah satunya adalah Produk Domestik Regional Bruto.

\section{Keberadaan Base Transceiver Station (BTS)}

Base Transceiver Station atau lebih sering dikenal dengan menara/tower BTS merupakan alat pengirim dan penerima sinyal komunikasi seluler (BPS, 2019).

\section{Subindeks Keahlian TIK}

Angka yang menggambarkan kemampuan atau keahlian dalam TIK atau ICT Skill (Badan Pusat Statistik, 2020).

\section{Model Regresi Berganda}

Analisis regresi merupakan model matematis yang menggambarkan prediksi variabel terikat dengan melibatkan variabel bebas. Dalam menentukan estimasi parameter model regresi digunakan metode Ordinary Least Square (OLS). Metode ini mensyaratkan pemenuhan uji asumsi klasik meliputi : 1). Data berdistribusi normal, 2). Tidak terjadi multikolinearitas, 3). Bebas dari autokorelasi, 4). Lolos uji heterodekastisitas. Model regresi yang baik adalah model regresi yang lolos keseluruhan uji asumsi klasik. Sebaliknya, model regresi OLS yang tidak lolos uji asumsi klasik kurang mampu menjelaskan fenomena data yang sebenarnya.

\section{Model Geographically Weighted Regression (GWR)}

Model GWR adalah suatu model pengembangan dari regresi global yang memperhatikan pengaruh spasial atau letak suatu lokasi pengamatan. Adanya pengaruh amatan lokasi ini menyebabkan hasil estimasi GWR berbeda dengan model regresi. Estimasi model regresi OLS memberikan hasil nilai parameter regresi bersifat global (sama) untuk semua lokasi pengamatan sedangkan pada model GWR nilai parameter bersifat lokal atau berbeda-beda untuk setiap lokasi pengamatan.

\section{Metode Penelitian}

\section{Jenis dan Sumber Data}

Penelitian ini menggunakan jenis data sekunder yang 
bersumber dari Badan Pusat Statistika (BPS). Adapun variabel respon yang digunakan pada penelitian ini adalah presentase usaha E-Commerce sedangkan untuk variabel prediktor meliputi PDRB, ketersediaan BTS, dan subindeks keahlian di bidang TIK dari seluruh provinsi di Indonesia periode tahun 2019.

\section{Metode Analisis Data}

Analisis data pada penelitian ini menggunakan metode regresi spasial. Adapun pengolahan data dengan bantuan software GWR4. Adapun diagram alir penelitian pada Gambar 2 berikut ini:

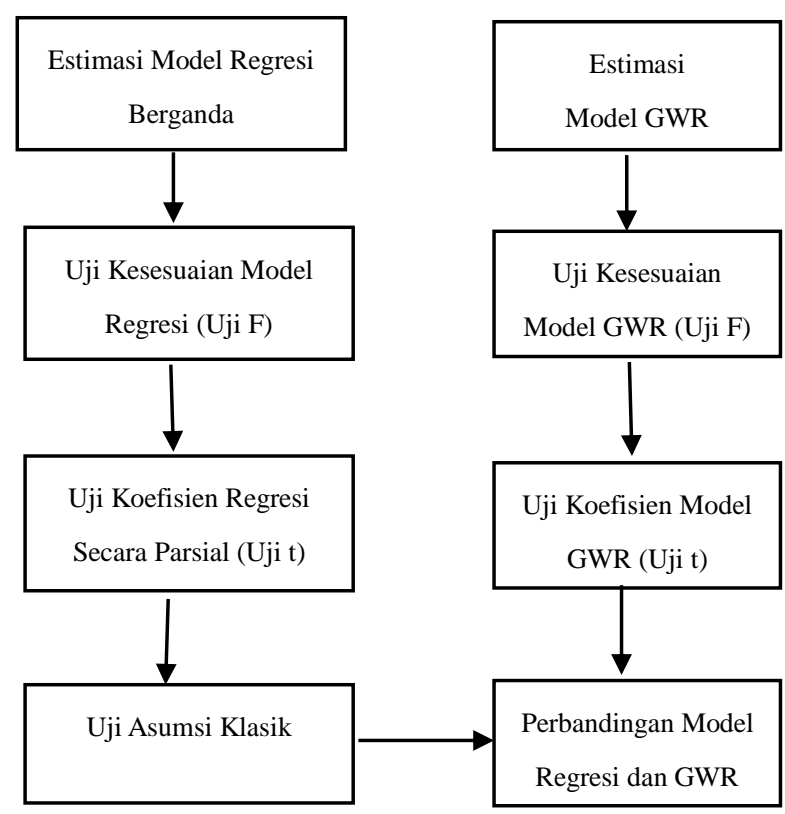

Gambar 2: Diagram Alir Penelitian

\section{Hasil Penelitian}

\section{Pendugaan Parameter Regresi Berganda}

Pada tahap pertama dilakukan analisis regresi berganda untuk melihat ada tidaknya pengaruh variabel bebas terhadap variabel terikat, tanpa memasukkan faktor lokasi pengamatan. Adapun hasil estimasi model regresi berganda diberikan pada Tabel 1 berikut.

TABEL 1.

NILAI KOEFISIEN DAN P- VALUE MODEL REGRESI BERGANDA

\begin{tabular}{|c|c|c|c|}
\hline Variabel & Koefisien & $t$-stat & P-Value \\
\hline Intersep & -19.795 & -1.445 & 0.159 \\
\hline BTS $\left(X_{1}\right)$ & 0.001 & 0.643 & 0.525 \\
\hline Ln PDRB $\left(X_{\mathcal{I}}\right)$ & 1.409 & 1.469 & 0.152 \\
\hline Keahlian $\left(X_{\unlhd}\right)$ & 2.671 & 1.762 & 0.088 \\
\hline F-Statistik & & 3.149 & \\
\hline P-Value $($ F-Stat $)$ & & & \\
\hline
\end{tabular}

\begin{tabular}{|c|c|}
\hline R-Square & 0.239 \\
\hline
\end{tabular}

Sumber: Data Diolah (2020)

Berdasarkan output pada Tabel 1, diperoleh nilai p-value untuk uji kesesuaian model sebesar $0.039<\alpha=$ 0.10 . Hal ini berarti variabel bebas berpengaruh signifikan secara bersama-sama terhadap variabel bebas. Sedangkan berdasarkan hasil uji parsial diperoleh bahwa variabel bebas yang signifikan terhadap variabel terikat hanya ada satu yaitu variabel keahlian dengan bentuk persamaan matematisnya sebagai berikut:

$$
\begin{aligned}
& E-\text { Commerce }(\%) \\
& =-19.795+0.001 X_{1}+1.409 X_{2}+2.671 X_{3}
\end{aligned}
$$

\section{Pengujian Asumsi Klasik}

Model regresi yang lolos syarat uji asumsi klasik merupakan model yang baik untuk merepresentasikan data. Uji asumsi klasik yang pertama adalah asumsi normalitas dalam model regresi. Hasil uji Kolmogorov-Smirnov menunjukkan nilai Asymp. Sig. (2-tailed) sebesar 0.200 lebih besar dari $\alpha=0.10$, sehingga dapat ditarik kesimpulan bahwa data berdistribusi normal.

Asumsi lainnya yang harus terpenuhi yaitu tidak terjadinya autokorelasi residual. Pengujian asumsi yang kedua menggunakan nilai Durbin-Watson (d). Dari hasil output SPSS diperoleh nilai DW $=2.177$. Nilai ini berada diantara nilai $d_{u}=1.6519$ dan $4-d_{u}=2.3481$ sehingga dapat disimpulkan tidak ada autokorelasi antar residual.

Syarat berikutnya adalah antar variabel prediktor tidak terjadi multikolinearitas. Untuk menguji asumsi tersebut digunakan nilai VIF. Adapun nilai VIF variabel prediktor diberikan pada Tabel 2 berikut:

TABEL 2.

NILAI VIF VARIABEL PREDIKTOR

\begin{tabular}{|c|c|}
\hline Variabel & VIF \\
\hline BTS & 2.070 \\
\hline LN PDRB & 1.974 \\
\hline Keahlian & 1.070 \\
\hline
\end{tabular}

Sumber: Data Diolah (2020)

Dari hasil output SPSS diperoleh nilai VIF pada variabel prediktor di bawah nilai 10 sehingga dapat disimpulkan bahwa seluruh variabel prediktor terbebas dari multikolinieritas.

Terakhir untuk syarat model regresi yang baik adalah uji asumsi residual identik atau lebih dikenal sebagai uji homokedastisitas. Berdasarkan hasil uji Breush-Pagan diperoleh nilai signifikansi sebesar 0.09 lebih kecil dibandingkan $\alpha=0.10$, artinya terjadi gejala 
heterokedastisitas dalam model regresi. Terlanggarnya asumsi homokedastisitas ini menguatkan dugaan adanya pengaruh letak geografis pada data persentase usaha E-Commerce di Indonesia.

\section{Pengujian Kesesuaian Model GWR}

Langkah pertama dalam pembentukan model GWR adalah menentukan letak geografis setiap provinsi di Indonesia yang diwakili oleh titik koordinat bujur dan lintang. Letak geografis setiap provinsi ini dimanfaatkan untuk mencari bandwidth optimum dengan menerapkan prosedur Cross Validation (CV) dan fungsi pembobot adaptif Gaussian. Dengan menggunakan bantuan software GWR4 diperoleh nilai bandwidth optimum dari hasil iterasi q: 5.000 dengan CV minimum sebesar 20.540 .

Langkah selanjutnya adalah melakukan uji kecocokan model untuk data persentase usaha E-Commerce di Indonesia.

TABEL 3.

ANOVA KERNEL GAUSSIAN

\begin{tabular}{|c|c|c|c|c|}
\hline Model & SS & DF & MS & F \\
\hline Global Residual & 617.329 & 30.00 & & \\
\hline $\begin{array}{c}\text { GWR } \\
\text { Improvement }\end{array}$ & 344.533 & 11.424 & 30.158 & \\
\hline GWR Residual & 272.797 & 18.576 & 14.686 & 2.05357 \\
\hline
\end{tabular}

Sumber : Data Diolah (2020)

Dari output model diperoleh nilai F-hitung $=2.05357$ yang lebih besar dibandingkan F-tabel $=1.9535$. Hal ini menunjukkan bahwa model GWR lebih baik dalam menjelaskan hubungan antara variabel prediktor dan variabel respon pada data persentase usaha E-Commerce dibandingkan model regresi OLS dengan tingkat kepercayaan $90 \%$. Hal ini juga selaras dengan hasil perbandingan nilai SSE dan $R^{2}$ yang dihasilkan oleh kedua model. Nilai SSE Model GWR lebih kecil dibandingkan model regresi OLS. Sebaliknya nilai $R^{2}$ model GWR lebih besar dibandingkan model regresi OLS.

TABEL 4.

PERBANDINGAN NILAI $R^{2}$ DAN SSE MODEL REGRESIOLS DAN MODEL GWR

\begin{tabular}{|c|c|c|}
\hline $\begin{array}{c}\text { Indikator } \\
\text { Pembanding }\end{array}$ & $\begin{array}{c}\text { Model Regresi } \\
\text { OLS }\end{array}$ & Model GWR \\
\hline SSE & 617.329339 & 272.796730 \\
\hline$R^{2}$ & 0.239418 & 0.663900 \\
\hline
\end{tabular}

Sumber : Data Diolah (2020)

Berdasarkan model terpilih, selanjutnya dilakukan analisis dengan menggunakan model GWR. Analisis dari model GWR memberikan hasil persamaan yang berbeda-beda untuk setiap provinsi di Indonesia sesuai dengan variabel prediktor yang signifikan di provinsi tersebut. Adapun variabel yang signifikan di 34 provinsi di Indonesia diberikan pada Tabel 5 . Berdasarkan Tabel 5 terbentuk lima pengelompokan provinsi berdasarkan variabel prediktor yang mempengaruhinya. Dari hasil uji parsial, terdapat perbedaan signifikansi variabel prediktor antara model GWR dengan model regresi berganda. Hasil estimasi parameter model regresi berganda bersifat global, artinya variabel keahlian berpengaruh signifikan terhadap usaha E-Commerce di seluruh provinsi Indonesia. Sedangkan model GWR memberikan signifikansi variabel prediktor yang bersifat lokal.

TABEL 5.

PROVINSI DAN VARIABEL PREDIKTOR YANG SIGNIFIKAN

\begin{tabular}{|c|c|c|}
\hline No & $\begin{array}{c}\text { Variabel } \\
\text { Signifikan }\end{array}$ & Provinsi \\
\hline 1 & LN PDRB & $\begin{array}{c}\text { Gorontalo, Sulawesi Utara, Sulawesi } \\
\text { Tengah, Maluku Utara, Maluku, } \\
\text { Sulawesi Barat. }\end{array}$ \\
\hline 2 & Keahlian & $\begin{array}{c}\text { Kalimantan Selatan, Kalimantan } \\
\text { Barat, NTB, Bali, Jawa Timur, Jawa } \\
\text { Barat, DKI Jakarta, Banten, Kep. } \\
\text { Bangka Belitung. }\end{array}$ \\
\hline 3 & $\begin{array}{c}\text { Keahlian dan } \\
\text { BTS }\end{array}$ & Jawa Tengah, DI Yogyakarta \\
\hline 4 & $\begin{array}{l}\text { Keahlian dan LN } \\
\text { PDRB }\end{array}$ & NTT, Papua Barat, Papua \\
\hline 5 & $\begin{array}{l}\text { Tidak ada yang } \\
\text { Signifikan }\end{array}$ & $\begin{array}{l}\text { Aceh, Riau, Kep. Riau, Sumatera } \\
\text { Utara, Lampung, Sumatera Barat, } \\
\text { Sumatera Selatan, Jambi, Bengkulu, } \\
\text { Kalimantan Timur, Kalimantan } \\
\text { Tengah, Kalimantan Utara, Sulawesi } \\
\text { Selatan, Sulawesi Tenggara. }\end{array}$ \\
\hline
\end{tabular}

Sumber : Data Diolah (2020)

Dari pengelompokan variabel prediktor yang signifikan terhadap persentase usaha E-Commerce di masing-masing provinsi di Indonesia maka dapat dibuat peta tematik sebaran faktor-faktor yang mempengaruhi persentase usaha E-Commerce di setiap provinsi di Indonesia. Adapun peta tematik diberikan pada Gambar 3 berikut.

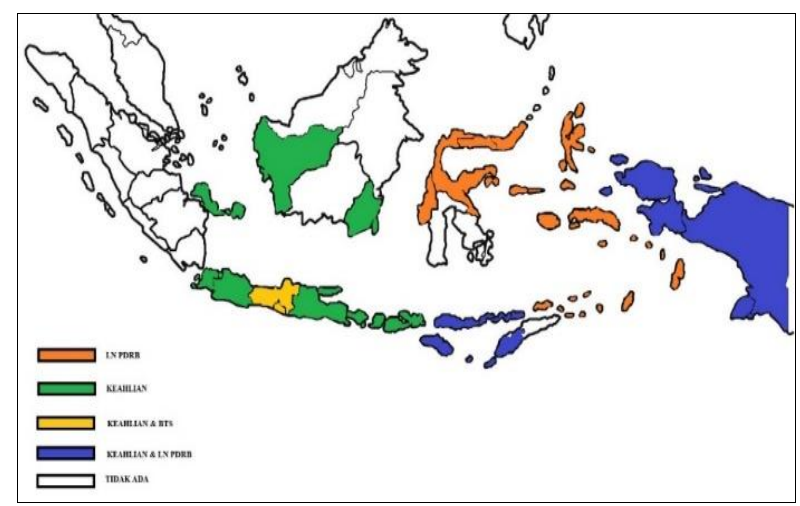

Gambar 3 : Peta Tematik Sebaran Variabel Prediktor (Data

133 | Jurnal Akuntansi, Ekonomi dan Manajemen Bisnis | Vol. 9 No.2, December 2021, 130-135 | E-ISSN: 2548-9836 
diolah, 2020)

Gambar 3 memperlihatkan bahwa setiap provinsi di Indonesia mempunyai variabel prediktor signifikan yang berbeda-beda. Selain itu, setiap provinsi juga memiliki persamaan yang berbeda sesuai dengan hasil estimasi model GWR. Sebagai contoh persamaan model GWR Jawa Tengah berdasarkan variabel yang signifikan diberikan pada persamaan berikut :

$$
\begin{aligned}
& \hat{y}_{\text {JawaTengah }}=-17,523+0,002 X_{1}+7,306 X_{3} \\
& R^{2}=0,903
\end{aligned}
$$

Selanjutnya persamaan model GWR untuk Papua sebagai berikut:

$$
\begin{aligned}
& \hat{y}_{\text {Pариа }}=-36,829+2,411 X_{2}+3,486 X_{3} \\
& R^{2}=0,619
\end{aligned}
$$

Dari persamaan (2) dan (3) terlihat bahwa variabel prediktor yang memengaruhi persentase usaha E-Commerce secara signifikan di Provinsi Jawa Tengah adalah ketersediaan BTS dan keahlian masyarakat dalam bidang TIK sedangkan untuk variabel yang memengaruhi persentase usaha E-Commerce di Provinsi Papua adalah PDRB dan keahlian masyarakat Papua dalam bidang TIK. Selanjutnya, untuk hasil estimasi parameter semua

\begin{tabular}{|c|c|c|c|c|c|c|}
\hline No & Provinsi & $\beta_{0}$ & $\beta_{1}$ & $\beta_{2}$ & $\beta_{3}$ & Local $R^{2}$ \\
\hline 1 & Aceh & 14.161 & 0.001 & -0.168 & 0.144 & 0.596 \\
\hline 2 & Sumatera Utara & 22.732 & 0.001 & -0.543 & -0.573 & 0.565 \\
\hline 3 & Sumatera Barat & 39.048 & 0.001 & -1.134 & -2.213 & 0.498 \\
\hline 4 & Riau & 39.068 & 0.001 & -1.271 & -1.875 & 0.469 \\
\hline 5 & Jambi & 7.633 & 0.001 & 0.052 & 0.955 & 0.492 \\
\hline 6 & Sumatera Selatan & 10.465 & 0.001 & 0.048 & 0.417 & 0.591 \\
\hline 7 & Bengkulu & 5.618 & 0.001 & 0.137 & 1.088 & 0.601 \\
\hline 8 & Lampung & -7.419 & 0.001 & 0.216 & 3.269 & 0.619 \\
\hline 9 & Kep. Bangka Belitung & -9.027 & 0.001 & 0.069 & 3.839 & 0.601 \\
\hline 10 & Kep. Riau & 8.662 & 0.001 & 0.076 & 0.692 & 0.524 \\
\hline 11 & Dki Jakarta & -15.155 & 0.002 & -0.600 & 6.355 & 0.804 \\
\hline 12 & Banten & -14.866 & 0.002 & -0.323 & 5.696 & 0.763 \\
\hline 13 & Jawa Barat & -15.476 & 0.002 & -0.608 & 6.424 & 0.814 \\
\hline 14 & Jawa Tengah & -17.524 & 0.002 & -0.877 & 7.306 & 0.903 \\
\hline 15 & Di Yogyakarta & -23.399 & 0.002 & -0.441 & 7.269 & 0.839 \\
\hline 16 & Jawa Timur & -24.525 & 0.002 & -0.092 & 6.670 & 0.786 \\
\hline 17 & Bali & -33.794 & 0.002 & 0.517 & 6.801 & 0.799 \\
\hline 18 & Nusa Tenggara Barat & -33.257 & 0.001 & 1.343 & 5.078 & 0.758 \\
\hline 19 & Nusa Tenggara Timur & -33.450 & 0.000 & 2.146 & 3.541 & 0.711 \\
\hline 20 & Kalimantan Barat & -11.440 & 0.001 & 0.476 & 3.341 & 0.583 \\
\hline 21 & Kalimantan Tengah & -14.260 & 0.001 & 0.733 & 3.288 & 0.540 \\
\hline 22 & Kalimantan Selatan & -17.034 & 0.001 & 0.856 & 3.440 & 0.608 \\
\hline 23 & Kalimantan Timur & -8.688 & 0.000 & 2.039 & -0.271 & 0.395 \\
\hline 24 & Kalimantan Utara & -12.448 & 0.000 & 1.963 & 0.510 & 0.456 \\
\hline 25 & Sulawesi Utara & -25.385 & -0.001 & 2.980 & 0.703 & 0.423 \\
\hline
\end{tabular}
provinsi di Indonesia diberikan pada Tabel 6 berikut:

TABEL 6

KOEFISIEN PARAMETER ESTIMASI MODEL GWR

134 | Jurnal Akuntansi, Ekonomi dan Manajemen Bisnis | Vol. 9 No.2, December 2021, 130-135 | E-ISSN: 2548-9836 


\begin{tabular}{|c|c|c|c|c|c|c|}
\hline 26 & Gorontalo & -15.639 & -0.003 & 4.014 & -2.609 & 0.340 \\
\hline 27 & Sulawesi Tengah & -6.628 & -0.002 & 3.018 & -2.396 & 0.363 \\
\hline 28 & Sulawesi Barat & -4.405 & -0.001 & 2.601 & -2.037 & 0.400 \\
\hline 29 & Sulawesi Selatan & -15.112 & 0.000 & 1.713 & 1.356 & 0.577 \\
\hline 30 & Sulawesi Tenggara & -3.313 & -0.001 & 2.519 & -2.067 & 0.401 \\
\hline 31 & Maluku & -33.313 & 0.000 & 2.507 & 2.708 & 0.533 \\
\hline 32 & Maluku Utara & -33.372 & -0.001 & 3.532 & 0.999 & 0.383 \\
\hline 33 & Papua Barat & -40.113 & 0.000 & 2.731 & 3.377 & 0.503 \\
\hline 34 & Papua & -36.829 & 0.000 & 2.411 & 3.486 & 0.619 \\
\hline
\end{tabular}

Sumber: Data Diolah (2020)

\section{Kesimpulan}

Berdasarkan hasil penelitian diperoleh simpulan, 1). Model GWR memberikan hasil analisis yang lebih baik dibandingkan dengan model regresi biasa, 2). Hasil analisis model GWR mampu mendeskripsikan variabel prediktor yang signifikan secara lokal berdasarkan masing-masing provinsi di Indonesia, 3). Data persentase usaha E-Commerce di Indonesia dapat dipetakan dalam lima kelompok sesuai dengan variabel prediktor yang signifikan yaitu (a) Pertumbuhan ekonomi berpengaruh signifikan terhadap persentase usaha E-Commerce di enam provinsi di Indonesia, (b) Keahlian di bidang TIK berpengaruh signifikan terhadap persentase usaha E-Commerce di sembilan provinsi di Indonesia, (c) Dua provinsi signifikan terhadap keahlian di bidang TIK dan ketersediaan BTS, (d) Keahlian di bidang TIK dan pertumbuhan ekonomi berpengaruh signifikan terhadap persentase usaha E-Commerce di tiga provinsi di Indonesia, (e) Persentase usaha E-Commerce di sebanyak empat belas provinsi di Indonesia tidak dipengaruhi oleh variabel prediktor yang digunakan pada penelitian ini.

Adapun saran untuk penelitian selanjutnya, 1). Pengkajian lebih mendalam terkait faktor-faktor yang mempengaruhi perkembangan usaha E-Commerce dengan variabel prediktor yang lain, 2). Hasil penelitian diharapkan dapat menjadi bahan pertimbangan pengambilan kebijakan dalam pengembangan E-Commerce terutama terkait dengan kewilayahan baik oleh pemerintah, masyarakat, maupun stakeholder.

\section{Daftar Pustaka}

A. Badan Pusat Statistik, Statistik E-Commerce 2019, Badan Pusat Statistik, Jakarta, 2019. Available at: https://www.bps.go.id/publication/2019/12 /18/fd1e96b05342e479a83917c6/statistik-e -commerce-2019.html.
B. Badan Pusat Statistik, Indeks Pembangunan Teknologi Informasi dan Komunikasi, Badan Pusat Statistik, Jakarta, 2019.

C. Lastri, W.A. dan Anis, A, “ Pengaruh E-Commerce, Inflasi, dan Nilai Tukar Terhadap Pertumbuhan Ekonomi Indonesia", Jurnal Kajian Ekonomi dan Pembangunan, 2(1), pp. 151-160,2020.

D. Merchant Machine (2019). Available at: https://merchantmachine.co.uk/saturated-sect ors/ (Accessed: 17 May 2021).

E. Muslim, A., "Efek Spillover Pertumbuhan Ekonomi Dan E-Commerce: Pola Spasial Pembangunan Ekonomi Di Sumatera" , Researchgate.Net, 2020.

F. Ramadhan, R. T. F., "Faktor-Faktor Yang Memengaruhi Perkembangan E-Commerce Serta

G. Pengaruhnya Terhadap Pendapatan Nasional Dan Pengangguran",Tesis, Institut Pertanian Bogor, 2019.

H. Sukirno, Sadono., Pengantar Makro Ekonomi. Raja Grafindo Persada, Jakarta, 2005. 